\title{
Bio efficacy of fungicides against rice sheath blight caused by Rhizoctonia solani under in vitro condition
}

\author{
T. SUTHIN RAJ*, K. HANE GRAFF AND H. ANN SUJI ${ }^{1}$ \\ Department of Plant Pathology, Faculty of Agriculture, Annamalai University, CHIDAMBARAM (T.N.) INDIA \\ ${ }^{1}$ Centre for Advance Studies in Marine Biology, Annamalai University, CHIDAMBARAM (T.N.) INDIA
}

\section{ARITCLE INFO}

Received : 07.03 .2016

Revised : 16.09 .2016

Accepted : 30.09 .2016

\section{KEY WORDS :}

Fungicides, Rhizoctonia solani, Antifungal compounds, Rice
*Corresponding author:

Email : suthinagri@gmail.com

\begin{abstract}
Sheath blight caused by Rhizoctonia solani Kuhn [Thanatephorus cucumeris (Frank) Donk], occurs throughout the temperate and tropical rice growing regions. Rice sheath blight was considered as a minor disease in earlier days, but now it is regarded as an internationally important disease second only to rice blast. Use of fungicides with a broad spectrum of activity against more than one disease is common in rice. The foliar spray of fungicides is the single most effective method for the management of sheath blight disease. The bio efficacy of various fungicides like Carbendazim 50 per cent WP, Mancozeb 50 per cent WP, Benomyl 50 per cent WP, Copper oxychloride 50 per cent WP, Edifenphos 50 per cent EC, Iprobenphos 50 per cent EC and Hexaconazole 5 EC were used to test against the $R$. solani by Poisoned food technique and Mycelial dry weight is analyzed. All the tested fungicides registered appreciable inhibition in colony growth and mycelia dry weight. Among the eight fungicides, Hexaconazole 200 ppm and $400 \mathrm{ppm}$ were completely inhibiting the mycelial growth of $R$. solani. Among the fungicides, Hexaconazole showed the highest level of inhibition and recorded 49.3 mg mean of mycelial dry weight. The result of the experiment revealed the superiority of Hexaconazole in the control of $R$. solani, hence the same was used for further studies.
\end{abstract}

How to view point the article : Raj, T. Suthin, Graff, K. Hane and Suji, H. Ann (2016). Bio efficacy of fungicides against rice sheath blight caused by Rhizoctonia solani under in vitro condition. Internat. J. Plant Protec., 9(2) : 615-618, DOI : 10.15740/HAS/IJPP/9.2/ 615-618 